

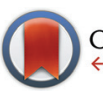

CrossMark \& click for updates

Cite this: Polym. Chem., 2015, 6. 7658

Received 20th July 2015,

Accepted 24th September 2015

DOI: $10.1039 / c 5 p y 01133 g$

www.rsc.org/polymers

\title{
Thienopentathiepine: a sulfur containing fused heterocycle for conjugated systems and their electrochemical polymerization $\dagger$
}

\author{
Sashi Debnath, Anjan Bedi and Sanjio S. Zade* \\ A series of conjugated building blocks based on the thieno[3,4-f][1,2,3,4,5]pentathiepine $\left(\mathrm{C}_{4} \mathrm{~S}_{6}\right)$ core has \\ been synthesized by a new synthetic approach. The structural and optoelectronic properties of $\mathrm{C}_{4} \mathrm{~S}_{6}$ - \\ derivatives are tuned by a judicious choice of end-capping. Chalcogenophene-capped derivatives $(\mathbf{2} \mathbf{d}, \mathbf{2} \mathbf{e}$, \\ 2f) were successfully electrochemically polymerized. The optical band gaps $\left(E_{\mathrm{g}}^{\mathrm{opt}}\right)$ of $\mathbf{P} \mathbf{1}, \mathbf{P} \mathbf{2}$ and $\mathbf{P} 3$ were \\ found to be in the range of 1.7-1.8 eV. A spectroelectrochemical study of the polymers showed reversibil- \\ ity in the formation of singly (polaron) and doubly charged (bipolaron) species.
}

\section{Introduction}

Thiophene-based conjugated systems represent one of the most widely investigated groups of $\pi$-conjugated materials ${ }^{1,2}$ because of the potential industrial applications of these materials as active materials in organic electronic devices such as organic light-emitting diodes (OLEDs), ${ }^{3}$ field-effect transistors (OFETs), ${ }^{4,5}$ and photovoltaic cells (OPVs). ${ }^{6,7}$ Structural modifications of the conjugated backbone are keystones to control the energy levels of the frontier orbitals and the optoelectronic properties of the resulting materials. ${ }^{8}$ Developing a synthetic approach for new $\pi$-conjugated building blocks with the desired optoelectronic properties is imperative as conjugated materials with suitable consequences are limited. ${ }^{9}$ Among the numerous chalcogenophene-based polymers, polythiophene (PT) derivatives have received growing attention because of their fundamental advantages such as (i) stronger donor characteristics, (ii) rigidity/crystallinity, (iii) good chemical stability, and (iv) high conductivity in the doped state.

Several strategies have been adopted to introduce new building blocks for conjugated materials with the desired properties. One of the important strategies includes synthesis of chalcogen containing heterocycles having multiple hetero-

Department of Chemical Sciences, Indian Institute of Science Education and Research (IISER) Kolkata, Mohanpur, 741246, India.

E-mail: sanjiozade@iiserkol.ac.in

$\dagger$ Electronic supplementary information (ESI) available: ${ }^{1} \mathrm{H}$ and ${ }^{13} \mathrm{C}$ NMR spectra of all new compounds, crystallographic data and refinement parameters of single crystal X-ray structures, the ORTEP and packing diagram of $2 \mathbf{a}$ and $2 \mathbf{c}$, spectroelectrochemistry of $\mathbf{P 3}$, TDDFT calculated molecular orbitals and excitations of 2d and 2e. CCDC 1049965, 1050201, 1050202 and 1050203. For ESI and crystallographic data in CIF or other electronic format see DOI: 10.1039/ c5py01133g atoms in the fused ring systems. An amplified spatial electronic arrangement because of the presence of multiple sulfur/ selenium atoms in the molecular building blocks delocalizes the charge efficiently. In this regard, we have reported diselenolodiselenole $\left(\mathrm{C}_{4} \mathrm{Se}_{4}\right)$ as a new building block for organic electronics, containing four selenium atoms in the central core. ${ }^{10}$

Chenard et al. reported the first synthesis of thieno[3,4-f]$[1,2,3,4,5]$ pentathiepine $\left(\mathrm{C}_{4} \mathrm{H}_{2} \mathrm{~S}_{6}\right)$ in $2 \%$ yield where 3,4 -dibromothiophene was used as a precursor. ${ }^{11}$ In spite of the accessibility of the thienopentathiepine $\left(\mathrm{C}_{4} \mathrm{~S}_{6}\right)$ derivatives, synthetic reports are scant. ${ }^{12-14}$ Although its nearest analogue benzopentathiepine has been explored to some extent its electrochemical properties were not investigated. ${ }^{15-17}$ Recently, Swager and coworkers reported multiple sulfur containing fused dithiolodithiole $\left(\mathrm{C}_{4} \mathrm{~S}_{4}\right)$ derivatives focusing on their interesting structural and optoelectronic properties, where the formation of thienopentathiepines was observed as side products. ${ }^{18}$ Here we report a new synthetic approach for the synthesis of thieno $[3,4-f][1,2,3,4,5]$ pentathiepine derivatives as novel conjugated building blocks containing a fused pentathiepine ring in bicyclic heterocycles. Optoelectronic and structural properties were tuned by a judicial choice of end capping of the central $\mathrm{C}_{4} \mathrm{~S}_{6}$ core. Chalcogenophene capped derivatives (2d, 2e, 2f) were electrochemically polymerized and the resulting polymers were successfully studied by spectroelectrochemistry.

\section{Results and discussion}

Synthesis of thieno[3,4-f $f[1,2,3,4,5]$ pentathiepine $\left(\mathrm{C}_{4} \mathrm{~S}_{6}\right)$ derivatives (2a-2f) involves heating of 1,4-disubstituted 1,3-butadiyne (1a-1f) with elemental sulfur near about the melting point of sulfur $\left(125{ }^{\circ} \mathrm{C}\right)$ for 0.5 hour in a closed-flask 


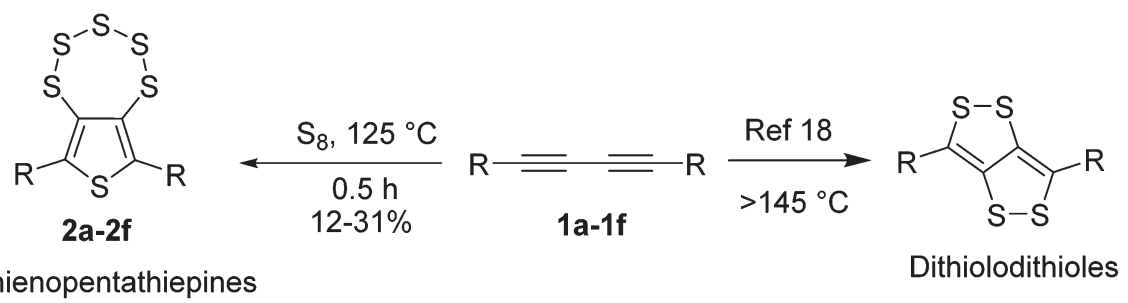

Thienopentathiepines

Dithiolodithioles

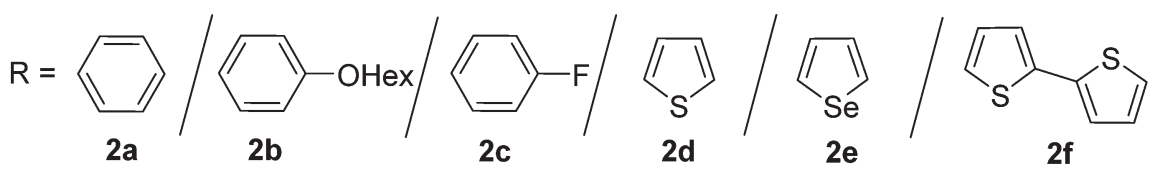

Scheme 1 Synthesis of $\mathrm{C}_{4} \mathrm{~S}_{6}$ derivatives $2 \mathrm{a}-2 \mathrm{f}$.

(Scheme 1). Without using any initiator/catalyst, the yields were obtained in the range of $12-31 \%$. This new synthetic approach is quick and simple compared to that of Chenard et al. and also benign in terms of precursors. The product yields did not improve by increasing the reaction time (up to 12 hours). In the presence of a solvent (1,2-dichloroethane) very low yields $(2-3 \%)$ were obtained. The reaction at higher temperature $\left(>150{ }^{\circ} \mathrm{C}\right)$ afforded $\mathrm{C}_{4} \mathrm{~S}_{4}$ derivatives as previously reported by Swager et al. ${ }^{18}$ The precursor diynes $\mathbf{1 a - 1 f}$ were prepared either by a previously reported procedure ${ }^{10,19,20}$ or by new synthetic strategies (see the ESI $\dagger$ ). The conversion of diynes to $\mathrm{C}_{4} \mathrm{~S}_{6}$ derivatives might proceed through the radical mechanism (Fig. $\mathrm{S} 1 \dagger)^{21}$

\section{Single crystal X-ray structures of $2 \mathrm{a}$ and $2 \mathrm{c}-2 \mathrm{e}$}

Crystals of 2a, and $\mathbf{2 c - 2 e}$ suitable for single crystal X-ray crystallography were obtained from slow evaporation of their dichloromethane solutions. In the molecular structure of $\mathbf{2 a}$, terminal phenyl rings are twisted from the central thiophene core by dihedral angles of $\sim 37^{\circ}$ and $\sim 45^{\circ}$ (Fig. S2a $\dagger$ ), whereas the packing diagram shows formation of $1 \mathrm{D}$ chains via intermolecular interactions $(\mathrm{S} 3-\mathrm{C} 8=3.40 \AA$ and $\mathrm{S} 4-\mathrm{S} 6=3.47 \AA$ ) (Fig. S2c $\dagger$ ). Similarly in the molecular structure of 2c (Fig. S2b $\dagger$ ), both $p$-fluoro substituted phenyl rings are twisted by a dihedral angle of $\sim 43^{\circ}$ from the central thiophene of the $\mathrm{C}_{4} \mathrm{~S}_{6}$-core. The structure of $2 \mathrm{c}$ exhibits resolute $\mathrm{S} \cdots \mathrm{S}$ intermolecular interaction ( $\mathrm{S} 4-\mathrm{S} 3=3.39 \AA$ and $\mathrm{S} 4-\mathrm{S} 5=3.39 \AA$ ). In the structures $\mathbf{2 a}$ and $\mathbf{2 c}$, the $\mathrm{S} \cdots \mathrm{S}$ interaction leads to the arrangement of a virtual $-(\mathrm{S}-\mathrm{S} \cdots \mathrm{S}-\mathrm{S})_{n}$ - polymeric chain along the $b$ - and $a$-axes, respectively (Fig. S2c and S2d $\dagger$ ).

In the molecular structure of $2 \mathbf{d}$ and $2 \mathbf{e}$, the terminal thiophene and selenophene rings are anti to the central thiophenes (Fig. 1). ${ }^{22}$ In the thiophene-capped $\mathrm{C}_{4} \mathrm{~S}_{6}$-derivative $2 \mathrm{~d}$, the torsional angles of the terminal thiophenes with the central thiophene of the $\mathrm{C}_{4} \mathrm{~S}_{6}$-core are $\sim 9^{\circ}$ and $\sim 23^{\circ}$, respectively; whereas in the selenophene-capped $\mathrm{C}_{4} \mathrm{~S}_{6}$-derivative $\mathbf{2 e}$, the corresponding torsional angles are $\sim 3^{\circ}$ and $\sim 7^{\circ}$. It is congruent with the earlier reports ${ }^{23,24}$ which showed that selenophene based conjugated systems are more planar and rigid because of the low aromaticity of selenophene and the higher polarizability of Se. In the crystal packing of $2 \mathbf{d}$, three molecules are connected by four $\mathrm{S} \cdots \mathrm{S}$ interactions $(\mathrm{S} 1-\mathrm{S} 8=3.56 \AA$ (two), S6-S6 = 3.48 , and S3-S7 = 3.47 $\mathrm{A}$ ) (Fig. 1b) to form a $2 \mathrm{D}$ zip-lock structure. ${ }^{25,26}$ In compound $2 \mathbf{e}$, Se $\cdots \mathrm{C}(\mathrm{Se} 2-\mathrm{C} 10=$ $3.55 \AA$ (forming $\pi$-stacking dimer) and Se2-C11 = 3.59 $\AA$ ) and S...S (S5-S6 = $3.43 \AA$ ) interactions form a typically $2 \mathrm{D}$ closed packed arrangement (Fig. 1d). In 2e, the S...S interaction constructs a $-(\mathrm{S}-\mathrm{S} \cdots \mathrm{S}-\mathrm{S})_{n}-$ polymeric chain.

\section{Optical and electrochemical properties of $2 \mathrm{a}-2 \mathrm{f}$}

Compounds 2a-2f exhibited two distinct absorption bands in their absorption spectra with absorption maxima $\left(\lambda_{\max }\right)$ ranging from 258 to $277 \mathrm{~nm}$ (high energy bands) and 316 to $429 \mathrm{~nm}$ (relatively broad and low energy bands) (Fig. 2a). TD-DFT calculations on $\mathbf{2 d}$ and $2 \mathrm{e}$ indicate that the lower energy absorption bands include (i) the $\pi \rightarrow \pi^{*}$ (HOMO $\rightarrow$ LUMO) transition of the terthiophene/selenophene-thiophene-selenophene backbone and (ii) the transition from the $\pi$-orbital of terthiophene/selenophene-thiophene-selenophene to the $\pi^{*}$ orbital of the central thiophene ring coupled with the antibonding orbitals of S-S bonds of the pentathiepine heterocycle (Tables S2 and S3†). The higher energy band mainly originates from (i) the transition from the $\pi$ orbital (HOMO) to the antibonding orbitals of the pentathiepine heterocycle and (ii) the non-bonding orbital on the $\mathrm{S}$ atoms of pentathiepine to the $\pi^{*}$ orbital (LUMO). Compounds with electron donating groups exhibited a bathochromic shift in the absorption spectra. The absorption spectrum of selenophene-capped $2 \mathbf{e}$ showed a red shift (of $27 \mathrm{~nm}$ ) compared to that of thiophenecapped $2 \mathbf{d}$ because of the better conjugation in $2 \mathbf{e}$. The bithiophene-capped $\mathrm{C}_{4} \mathrm{~S}_{6}$-derivative $2 \mathrm{f}$ showed lower-energy absorption bands due to the extended conjugation.

Cyclic voltammograms (CV) of 2a-2f showed irreversible oxidation peaks ranging from $0.80 \mathrm{~V}$ to $1.60 \mathrm{~V}$ vs. $\mathrm{Ag} / \mathrm{AgCl}$ (Fig. 2b). ${ }^{27}$ Although selenophene is electron rich compared to thiophene, 2e exhibited higher oxidation potential than $\mathbf{2 d}$. The planar conjugated backbone of $2 \mathbf{e}$ could result in superior delocalization of the electrons throughout the molecular plane, which might decrease the electron density on the $\mathrm{C}_{4} \mathrm{~S}_{6}$ 

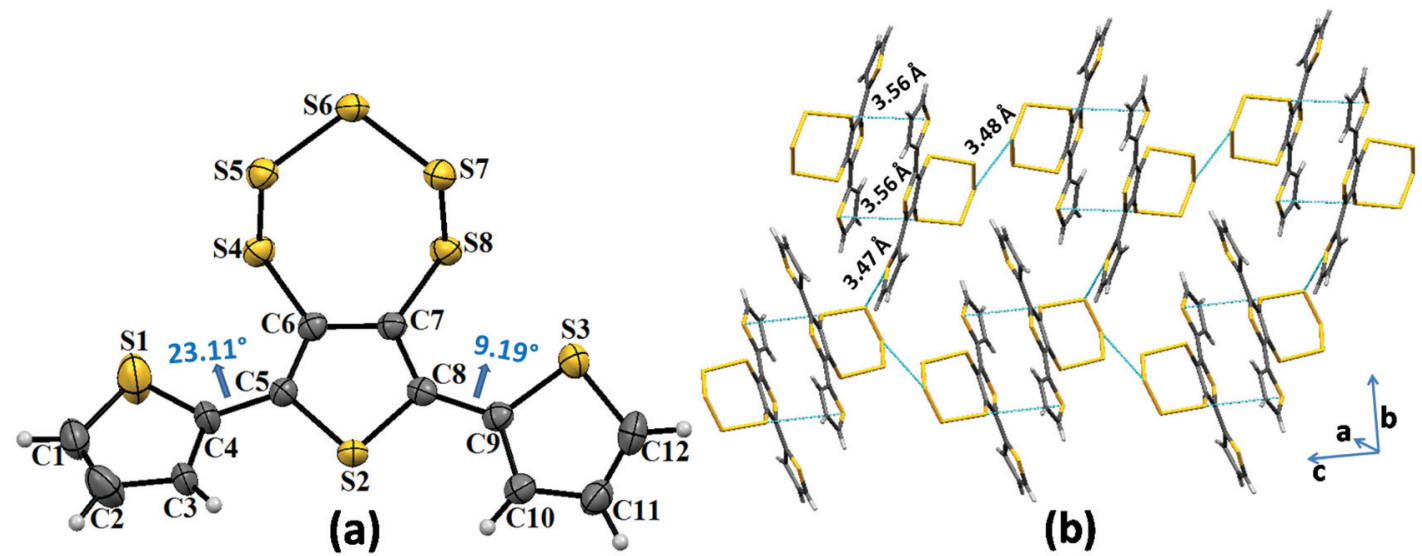

(b)
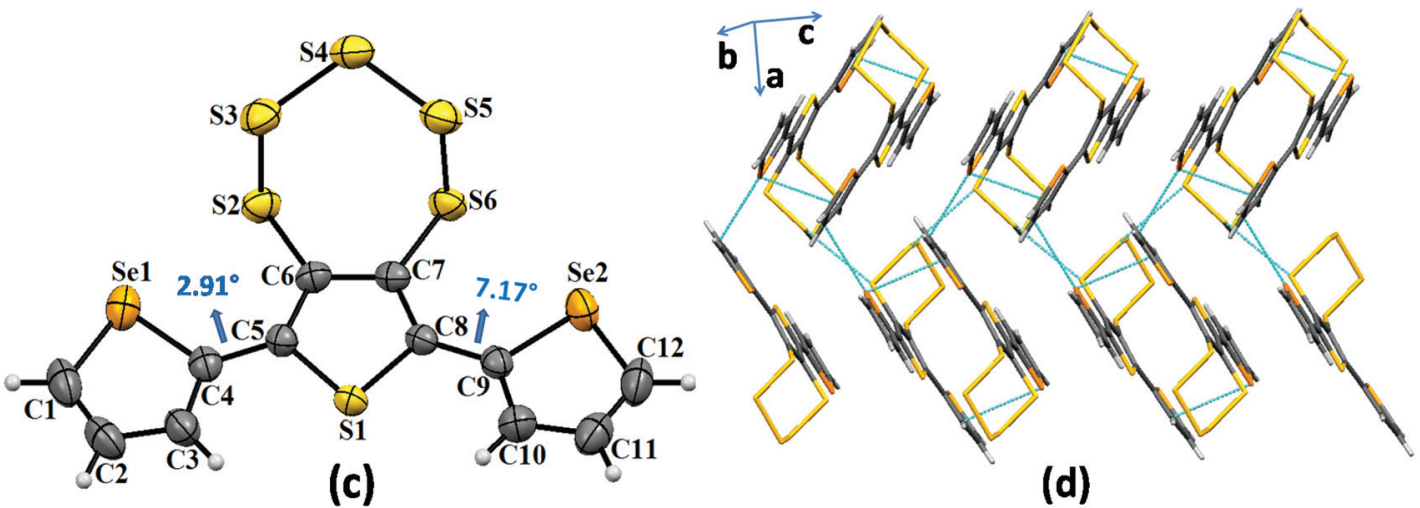

(d)

Fig. 1 (a) and (c) ORTEP diagram of $\mathbf{2 d}$ and $\mathbf{2 e}$, (b) and (d) packing of $\mathbf{2 d}$ and $\mathbf{2 e}$. The ellipsoids are drawn at the $50 \%$ probability level in (a) and (c).

(a)

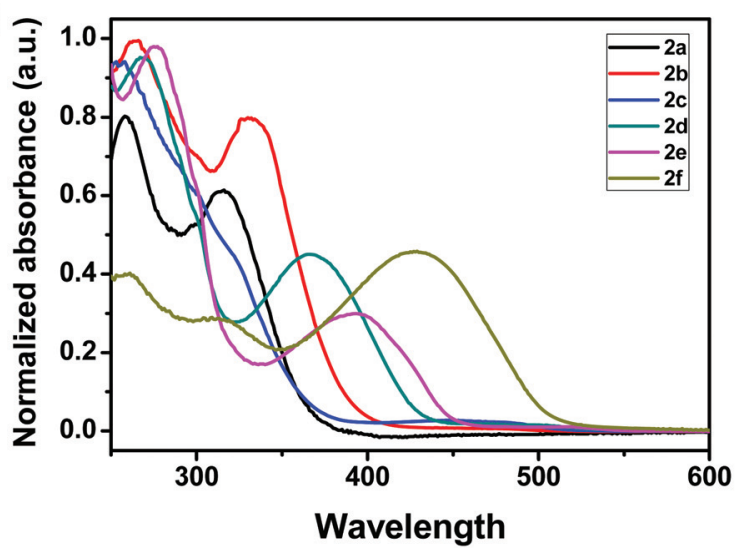

(b)

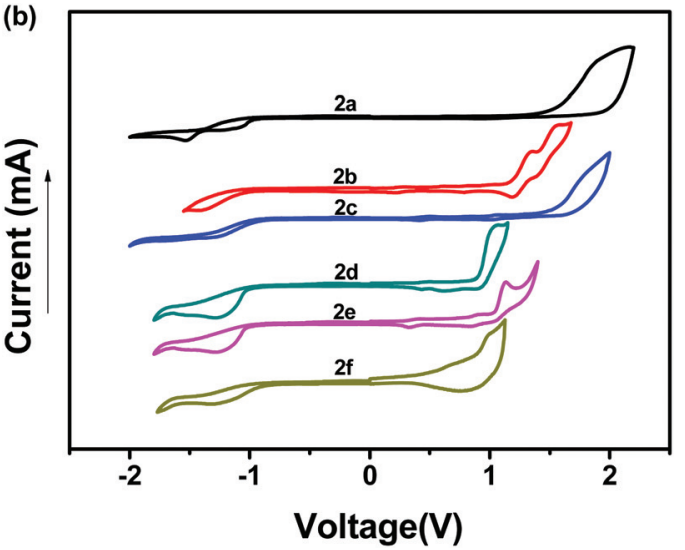

Fig. 2 (a) UV-vis spectra in DCM and (b) electrochemical properties of compounds $2 a-2 f$ in 0.1 M TBAPF 6 in dry DCM as the solvent using a Pt-disk working electrode, a Pt-wire counter electrode and a $\mathrm{Ag} / \mathrm{AgCl}$ reference electrode.

unit. The UV-vis and CV data were used to measure the band gap $\left(E_{\mathrm{g}}\right)$ and HOMO/LUMO energy levels (Table 1).

\section{Electrochemical properties of the polymers}

Under repeated CV cycles, compounds $2 \mathbf{d}, \mathbf{2 e}$ and $2 \mathbf{f}$ polymerized smoothly via progressive growth of a visible polymer film a platinum-disk working electrode (Scheme 2, Fig. 3, and $\mathrm{S} 3 \dagger$ ). The polymer films were investigated for their scan rate dependence at $50-250 \mathrm{mV} \mathrm{s}^{-1}$ for $\mathbf{P} 1$ and $50-300 \mathrm{mV} \mathrm{s}^{-1}$ for $\mathbf{P} 2$ and P3. All the polymers showed linear scaling of the anodic currents with the increasing value of scan rate (Fig. 3c, d and $\mathrm{S} 3 \dagger)$, as expected from an electrode-supported electroactive 
Table 1 Yields, absorption and electrochemical properties of $2 a-2 f$

\begin{tabular}{|c|c|c|c|c|c|c|}
\hline Compounds & \% Yield & $\lambda_{\max }(\mathrm{nm})$ & $E_{\text {onset }}^{\text {ox }}(\mathrm{V})$ & $E_{\mathrm{g}}^{\mathrm{opt} a}(\mathrm{eV})$ & $E_{\text {Номо }}^{b}(\mathrm{eV})$ & $E_{\text {LUMO }}{ }^{c}(\mathrm{eV})$ \\
\hline $2 a$ & 27 & 258,316 & 1.53 & 3.40 & -5.97 & -2.57 \\
\hline $2 \mathbf{b}$ & 31 & 266,330 & 1.14 & 3.22 & -5.58 & -2.36 \\
\hline $2 d$ & 17 & 270,366 & 0.90 & 2.87 & -5.34 & -2.47 \\
\hline $2 \mathrm{e}$ & 12 & 277,393 & 1.01 & 2.73 & -5.44 & -2.71 \\
\hline $2 f$ & 21 & 261,429 & 0.76 & 2.45 & -5.20 & -2.75 \\
\hline
\end{tabular}

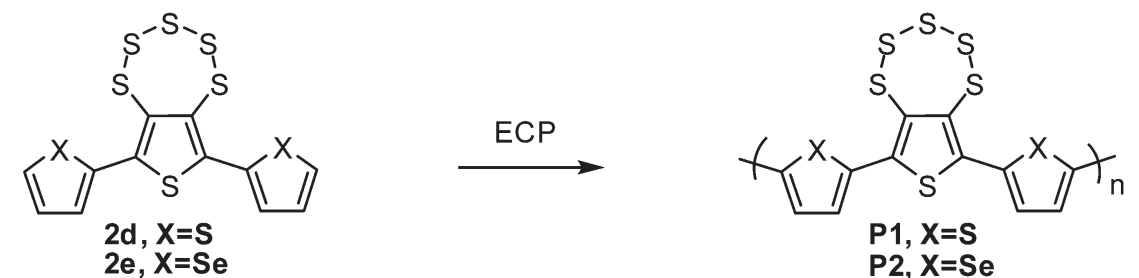<smiles>CC(F)(F)c1ccc(-c2ccc(-c3sc(-c4ccc(-c5ccc(C(F)(F)F)s5)s4)c4ssssssc34)s2)s1</smiles>

Scheme 2 Synthesis of polymers P1, P2 and P3.
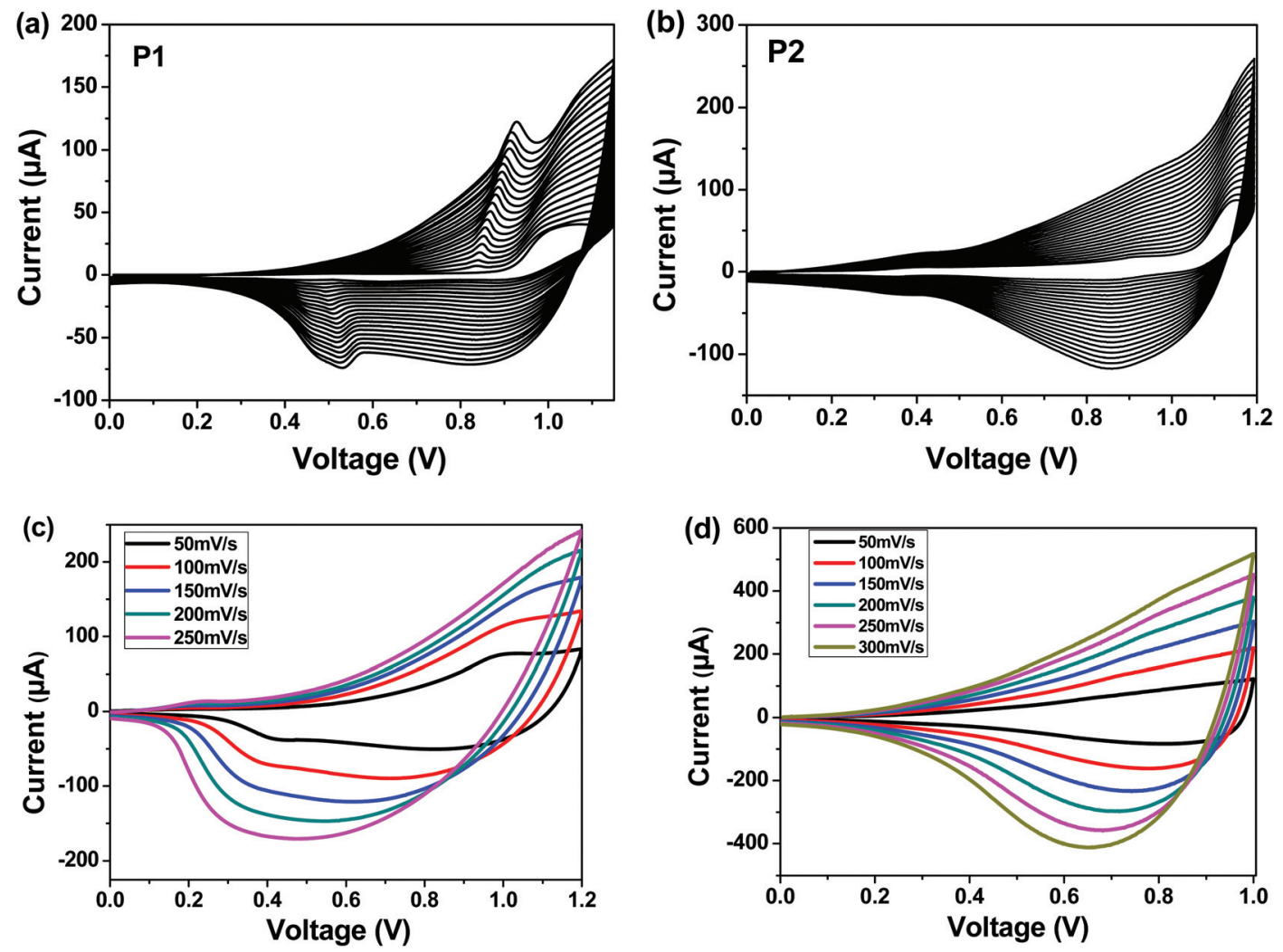

Fig. 3 (a) and (b) Multisweep electropolymerization of $2 \mathrm{~d}$ and $2 \mathrm{e}$ on a Pt electrode in DCM and $0.1 \mathrm{M} \mathrm{TBAPF} 6$ at $50 \mathrm{mV} \mathrm{s}{ }^{-1}$ vs. Ag/AgCl wire. (c) and (d) $\mathrm{CV}$ of $\mathrm{P} 1$ and $\mathrm{P} 2$ in monomer free DCM and $0.1 \mathrm{M} \mathrm{TBAPF}_{6}$ as a function of scan rate. 
film. Cyclic voltammograms of P1, P2, and P3 polymer films on a Pt working electrode showed quasi-reversible p-doping/ dedoping processes over a positive potential range in the DCM/0.1 M TBAPF 6 solvent/electrolyte system at $50 \mathrm{mV} \mathrm{s}^{-1}$ scan rate (Fig. 4b). The onsets of the oxidation potentials ( $E_{\text {onset }}^{\text {ox }}$ ) of P1, P2 and P3 were found to be $0.67,0.49$ and 0.43 $\mathrm{V}$, respectively, corresponding to the HOMO levels at -5.11 , -4.93 and $-4.87 \mathrm{eV}$, respectively. The LUMO levels, estimated from the HOMO and the onsets of the absorption peaks, were found to be $-3.35,-3.27$, and $-3.07 \mathrm{eV}$ for P1, P2, and P3, respectively (Fig. 4, Table 2). P2 exhibited a lower oxidation potential than $\mathbf{P 1}$, which can be attributed to the presence of more polarizable Se.

\section{Spectroelectrochemistry}

Polymers were chronoamperometrically deposited on an ITOcoated glass electrode from $1 \times 10^{-2} \mathrm{M}$ monomer solutions in DCM and the spectroelectrochemical properties were investigated in situ in the monomer-free electrolyte solution under a variety of voltage pulses. The absorption spectra in the UV-visNIR region of P1, P2 and P3 films (Fig. 5, S4 $\dagger$ ) revealed good electrochromic nature at distinct applied potentials in the $\mathrm{DCM} / \mathrm{TBAPF}_{6}$ solvent/electrolyte couple. The onset values of the lowest energy bands correspond to the optical band gaps $\left(E_{\mathrm{g}}^{\text {opt }}\right)$ of $1.76,1.69$ and $1.80 \mathrm{eV}$ for P1, P2 and P3, respectively (Table 2). P2 exhibited a smaller band gap than $\mathbf{P 1}$ because of (a)

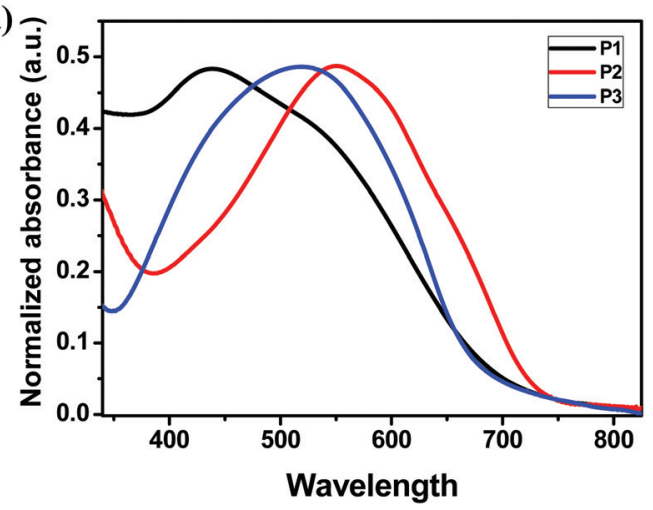

(b)

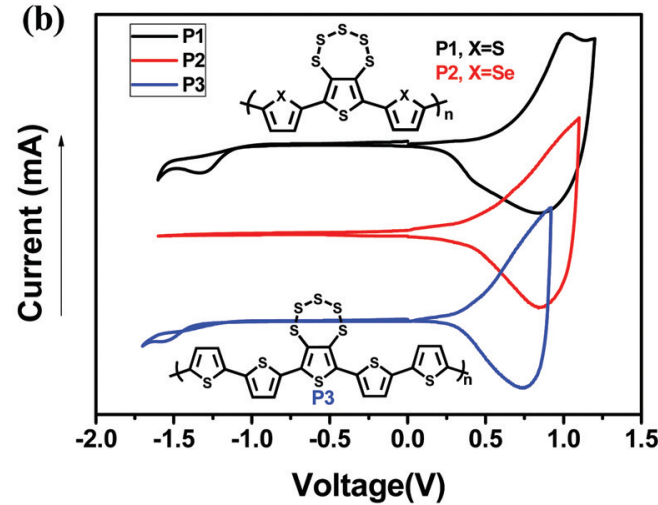

Fig. 4 (a) Absorption spectra of P1-P3 in thin film. (b) CV of P1, P2 and P3, using the DCM/TBAPF 6 solvent/electrolyte system.

Table 2 Absorption and electrochemical properties of P1, P2 and P3

\begin{tabular}{llllll}
\hline Polymer & $\lambda_{\max }(\mathrm{nm})$ & $E_{\mathrm{g}}^{\text {opt }}(\mathrm{eV})$ & $E_{\text {onset }}^{\text {ox }}(\mathrm{V})$ & $E_{\text {HOMO }}(\mathrm{eV})$ & -3.11 \\
\hline P1 & 439 & 1.76 & 0.67 & -4.93 & -3.35 \\
P2 & 550 & 1.69 & 0.49 & -4.87
\end{tabular}
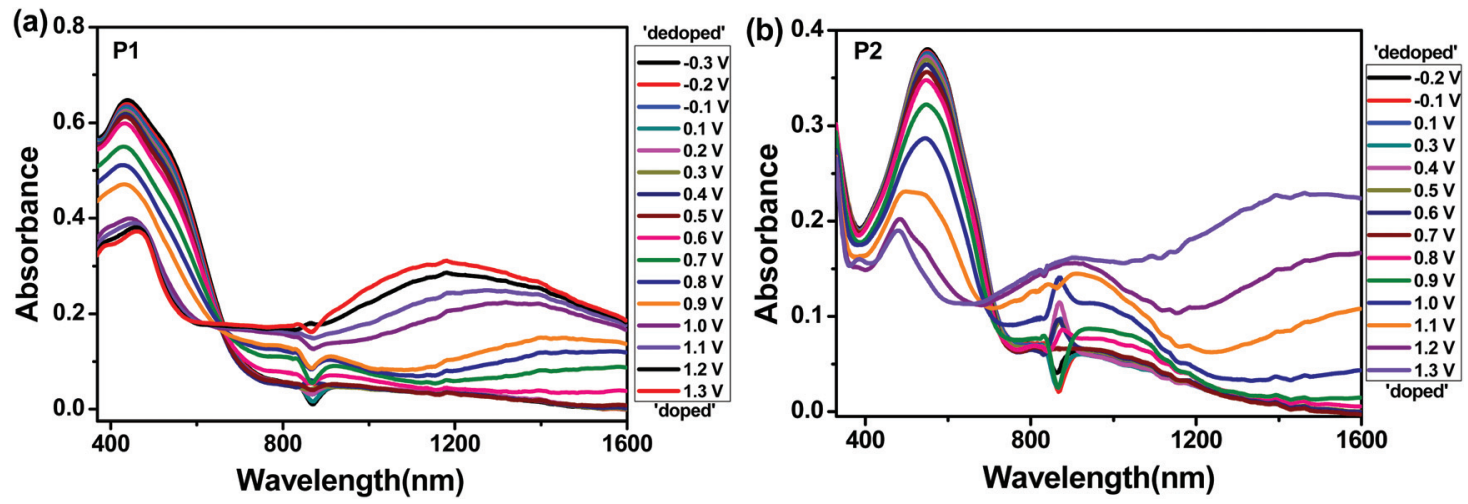

Fig. 5 Spectroelectrochemistry of (a) P1 and (b) P2 thin films prepared on ITO-coated glass as a function of applied potential between -0.3 and $+1.3 \vee$ for $\mathrm{P} 1$, and -0.2 and $+1.3 \vee$ for $P 2$ in $D C M$. 
the presence of selenophene in $\mathbf{P 2}$ instead of thiophene in P1. Notably, these polymers having the fused pentathiepine ring as a substituent on thiophene possess a smaller band gap compared to polythiophene $(2.0 \mathrm{eV})$ and polyselenophene (1.9 $\mathrm{eV}) .^{2,28,29}$ The band gaps of all three polymers remained in between the band gaps of poly(3-hexylthiophene) $(1.9 \mathrm{eV})$ and poly(3-hexylselenophene) $(1.6 \mathrm{eV}) .^{30,31}$ The lowering in the band gap of these polymers can be attributed to the delocalization of the $\pi$ electron density over the pentathiepine rings and interchain interactions due to the presence of multiple sulphur atoms.

In the spectroelectrochemical experiments, switching of the polymers from neutral to oxidized states was associated with the color change from deep brown to transparent-peach for P1, purple to transparent-gray for $\mathbf{P} 2$, and violet to transparentgray for $\mathbf{P 3}$. With the increasing applied potential, the intensity of the absorption band in the visible region (arises due to the $\pi-\pi^{*}$ transition) was gradually decreased and two new bands gradually appeared in the higher wavelength region. New peaks at 820, 905, and $750 \mathrm{~nm}$ for P1, P2 and P3, respectively, in their absorption spectra (Fig. 5 and $\mathrm{S} 4 \dagger$ ) indicate the formation of singly charged species (polaron), while the lower energy bands at 1180,1480 , and $1160 \mathrm{~nm}$ correspond to the formation of doubly charged species (bipolaron), respectively. ${ }^{32,33}$ The deviation in spectroelectrochemical experiments precisely comes at $850 \mathrm{~nm}$ (Fig. 5a and b) which is due to the lamp change (deuterium to tungsten lamp) during the NIR region to VIS region transformation.

\section{Conclusion}

In conclusion, a series of conjugated compounds, thieno[3,4-f] $[1,2,3,4,5]$ pentathiepine derivatives, was synthesized by a simple synthetic method of heating diaryl diynes with elemental sulfur. The structural and optoelectronic properties of $\mathrm{C}_{4} \mathrm{~S}_{6^{-}}$ derivatives were tuned successfully by the choice of end capping. Multiple close S $\cdots \mathrm{S}$ contacts due to the presence of a fused pentathiepine ring in $\mathrm{C}_{4} \mathrm{~S}_{6}$-derivatives and their polymers may be beneficial for the extended conjugation and charge transport. The $\mathrm{C}_{4} \mathrm{~S}_{6}$-derivatives with thiophene- and selenophene-capping were successfully electrochemically polymerized. The low band gap polymers P1-P3 exhibited well-defined spectroelectrochemistry and sufficient stability in the oxidized state, which can be exploited for organic electronic devices.

\section{Experimental section}

Most of the reagents and solvents of reagent grade were obtained from commercial sources and used without any further purification. NMR spectra were recorded on a Jeol-ECS $400 \mathrm{MHz}$ spectrometer using $\mathrm{CDCl}_{3} / \mathrm{C}_{6} \mathrm{D}_{6}$ as the solvent and chemical shifts are reported in parts per million ( $\delta$ scale) relative to tetramethylsilane (TMS) as the internal standard. Columns were equipped with silica gel (100-200 mesh). A nonaqueous $\mathrm{Ag} / \mathrm{AgCl}$ electrode was made by dipping silver wire into a $\mathrm{FeCl}_{3} / \mathrm{HCl}$ solution. Electrochemical analysis was carried out with a Princeton Applied Research 263A potentiostat using a platinum (Pt) disk electrode (dia. $1.6 \mathrm{~mm}$ ) as the working electrode, a platinum wire as the counter electrode, and an $\mathrm{AgCl}$ coated $\mathrm{Ag}$ wire as the reference electrode. Pt disk electrodes were gleamed with alumina, water, and acetone and were dried with nitrogen to remove any incipient oxygen. The electrolyte used was $0.1 \mathrm{M} \mathrm{TBAPF}_{6}$ in DCM. Films were electrodeposited in $0.1 \mathrm{M} \mathrm{TBAPF}_{6}$ in DCM by cyclic voltammetry (CV) between various applied potentials at $50 \mathrm{mV} \mathrm{s}^{-1}$ for 20 cycles. 2d, 2e and $2 \mathbf{f}$ were electrochemically polymerized on indium tin oxide (ITO) coated glass as a working electrode. Before examining the optical properties of polymer films, the films were rinsed with DCM. UV-vis-NIR spectra were recorded on a HITACHI U-4100 UV-vis-NIR spectrophotometer.

Fine crystals of $\mathbf{2 a}$ and $\mathbf{2 c - 2 e}$ were collected on a SuperNova, Dual, $\mathrm{Cu} / \mathrm{Mo}$ at zero, Eos diffractometer. Using Olex $2,{ }^{34}$ the structure was solved with the Superflip ${ }^{35}$ structure solution programme applying Charge Flipping and refined with the ShelXL ${ }^{36}$ refinement package applying least squares minimization.

\section{Synthesis of $1 \mathrm{e}$}

A tetrabutylammonium fluoride solution ( $3 \mathrm{~mL}, 1 \mathrm{M}$ in THF) was added dropwise into a stirred solution of trimethyl(selenophen-2-ylethynyl)silane (500 mg, $2.19 \mathrm{mmol}$ ) in $10 \mathrm{~mL}$ THF and stirred for $10 \mathrm{~min}$ at $\mathrm{rt}$. This solution was added into a three necked round-bottom flask containing $\mathrm{Cu}(\mathrm{OAc})_{2}$ (553 mg, $3.06 \mathrm{mmol}$ ) and $10 \mathrm{~mL}$ of pyridine/methanol mixture $(1: 1 \mathrm{v} / \mathrm{v})$ and refluxed for $2 \mathrm{~h}$. The reaction mixture was allowed to cool at rt and added to crushed-ice and $3.6 \mathrm{~mL}$ of $9 \mathrm{M} \mathrm{H}_{2} \mathrm{SO}_{4}$. The resulting solution was extracted with diethyl ether $(3 \times$ $25 \mathrm{~mL}$ ). The ether layers were mixed, dried over anhydrous $\mathrm{Na}_{2} \mathrm{SO}_{4}$ and concentrated to produce a deep brown crude product. Column chromatography of the crude on silica gel using hexane as the eluent gave 1e as a pale yellow solid $(170 \mathrm{mg}, 50 \%) .{ }^{1} \mathrm{H}$ NMR $\left(400 \mathrm{MHz}, \delta, \mathrm{ppm}, \mathrm{CDCl}_{3}\right): 8.07$ (d, $2 \mathrm{H}$, $J=4.6 \mathrm{~Hz}), 7.54(\mathrm{~d}, 2 \mathrm{H}, J=3.44 \mathrm{~Hz}), 7.24-7.21(\mathrm{~m}, 2 \mathrm{H},) .{ }^{13} \mathrm{C}$ NMR (100 MHz, $\left.\mathrm{CDCl}_{3}\right): \delta 136.6,134.9,129.6,126.0,79.6,79.5$.

\section{Synthesis of $1 \mathrm{f}$}

Compound $1 \mathbf{f}$ was synthesized by using a similar synthetic procedure to 1e using (2,2'-bithiophen-5-ylethynyl)trimethylsilane (563 $\mathrm{mg}, 2.15 \mathrm{mmol}$ ), which afforded $1 \mathrm{f}$ as a pale brown solid (300 mg, 73\%). ${ }^{1} \mathrm{H}$ NMR (400 MHz, $\delta$, ppm, $\mathrm{C}_{6} \mathrm{D}_{6}$ ): $6.83(\mathrm{~d}, 2 \mathrm{H}$, $J=3.84 \mathrm{~Hz}), 6.80(\mathrm{~d}, 2 \mathrm{H}, J=3.84 \mathrm{~Hz}), 6.65(\mathrm{~d}, 2 \mathrm{H}, J=5.36 \mathrm{~Hz})$, 6.57-6.52 (m, 4H). ${ }^{13} \mathrm{C}$ NMR $\left(100 \mathrm{MHz}, \mathrm{C}_{6} \mathrm{D}_{6}\right): \delta 140.9,136.5$, 135.8, 128.1, 125.5, 125.0, 123.8, 120.6, 79.8, 78.1.

\section{General procedure for the synthesis of $2 \mathrm{a}-2 \mathrm{f}$}

Butadienes $(1 \mathrm{mmol})$ and sulfur powder $(8 \mathrm{mmol})$ were charged into a Schlenk flask and it was stoppered. The reaction mixture was heated at $125{ }^{\circ} \mathrm{C}$ for $0.5 \mathrm{~h}$. The reaction was cooled and the resulting residue was purified by column chromatography on $100-200$ mesh silica gel $\left(2 \% \mathrm{CH}_{2} \mathrm{Cl}_{2}\right.$ in hexane) to obtain the products. 
2a: Yellowish brown solid. Yield: $106 \mathrm{mg}, 27 \%$. M.p.: $154{ }^{\circ} \mathrm{C}$. UV-vis in DCM: $\lambda_{\max }(\mathrm{nm})\left(10^{4} \times \varepsilon\left(\mathrm{M}^{-1} \mathrm{~cm}^{-1}\right)\right)=258$ (4.5), 316 (3.4). ${ }^{1} \mathrm{H}$ NMR (400 $\left.\mathrm{MHz}, \mathrm{CDCl}_{3}\right): \delta 7.55-7.51(\mathrm{~m}$, $2 \mathrm{H}), 7.49-7.43(\mathrm{~m}, 3 \mathrm{H}) .{ }^{13} \mathrm{C} \mathrm{NMR}\left(100 \mathrm{MHz}, \mathrm{CDCl}_{3}\right): \delta$ 148.3, 137.9, 132.5, 130.0, 129.1, 128.5. HRMS (ESI+): calculated for $\mathrm{C}_{16} \mathrm{H}_{10} \mathrm{~S}_{6}, 393.9107$; found 393.9029 .

2b: Yellow solid. Yield: $184 \mathrm{mg}, 31 \%$. M.p.: $122{ }^{\circ} \mathrm{C}$. UV-vis in DCM: $\lambda_{\max }(\mathrm{nm})\left(10^{4} \times \varepsilon\left(\mathrm{M}^{-1} \mathrm{~cm}^{-1}\right)\right)=266$ (5.9), 330 (4.7). ${ }^{1} \mathrm{H}$ NMR (400 MHz, $\left.\mathrm{CDCl}_{3}\right): \delta 7.46(\mathrm{~d}, 2 \mathrm{H}, J=8.4 \mathrm{~Hz}), 6.97(\mathrm{~d}$, $2 \mathrm{H}, J=8.4 \mathrm{~Hz}), 4.00(\mathrm{t}, 2 \mathrm{H}), 1.80(\mathrm{~m}, 2 \mathrm{H}), 1.51-1.43(\mathrm{~m}, 2 \mathrm{H})$, 1.38-1.32 (m, 4H), 0.91 (t, 3H). ${ }^{13} \mathrm{C}$ NMR (100 MHz, $\left.\mathrm{CDCl}_{3}\right)$ : $\delta$ 159.9, 147.9, 136.8, 131.2, 124.7, 114.4, 68.1, 31.5, 29.1, 25.7, 22.5, 14.0. HRMS (ESI+): calculated for $\mathrm{C}_{28} \mathrm{H}_{34} \mathrm{O}_{2} \mathrm{~S}_{6}, 594.0883$; found 594.0229 .

2c: Yield: $94 \mathrm{mg}, 22 \%$. M.p.: $143{ }^{\circ} \mathrm{C}$. UV-vis in DCM: $\lambda_{\max }$ $(\mathrm{nm})\left(10^{-4} \times \varepsilon\left(\mathrm{M}^{-1} \mathrm{~cm}^{-1}\right)\right)=258$ (7.8). ${ }^{1} \mathrm{H}$ NMR $(400 \mathrm{MHz}$, $\left.\mathrm{CDCl}_{3}\right): \delta$ 7.53-7.48 (m, 2H), 7.19-7.13 (m, 2H). ${ }^{13} \mathrm{C}$ NMR $\left(100 \mathrm{MHz}, \mathrm{CDCl}_{3}\right): \delta 164.2(\mathrm{~d}, J=199.3 \mathrm{~Hz}), 138.1,134.5(\mathrm{~d}, J=$ $6.5 \mathrm{~Hz}), 131.9$ (d, $J=6.5 \mathrm{~Hz}), 128.5,115.8$ (d, $J=18.05 \mathrm{~Hz}$ ). HRMS (ESI+): calculated for $\mathrm{C}_{16} \mathrm{H}_{8} \mathrm{~F}_{2} \mathrm{~S}_{6}, 429.8918$; found 429.8120 .

2d: Yellowish brown solid. Yield: $68 \mathrm{mg}, 17 \%$. M.p.: $167{ }^{\circ} \mathrm{C}$. UV-vis in DCM: $\lambda_{\max }(\mathrm{nm})\left(10^{-4} \times \varepsilon\left(\mathrm{M}^{-1} \mathrm{~cm}^{-1}\right)\right)=270$ (9.5), 366 (4.4). ${ }^{1} \mathrm{H}$ NMR (400 MHz, $\mathrm{CDCl}_{3}$ ): $\delta 7.45$ (d, 2H, $J=3.80$ $\mathrm{Hz}), 7.40(\mathrm{~d}, 2 \mathrm{H}, J=3.84 \mathrm{~Hz}), 7.18-7.07(\mathrm{~m}, 2 \mathrm{H}) .{ }^{13} \mathrm{C}$ NMR $\left(100 \mathrm{MHz}, \mathrm{CDCl}_{3}\right): \delta 140.5,136.7,133.8,128.5,128.4,127.3$. HRMS (ESI+): calculated for $\mathrm{C}_{12} \mathrm{H}_{6} \mathrm{~S}_{8}, 405.8235$; found 404.8191 .

2e: Yellowish brown solid. Yield: $60 \mathrm{mg}, 12 \%$. M.p.: $179{ }^{\circ} \mathrm{C}$. UV-vis in DCM: $\lambda_{\max }(\mathrm{nm})\left(10^{-4} \times \varepsilon\left(\mathrm{M}^{-1} \mathrm{~cm}^{-1}\right)\right)=277$ (10.5), 393 (3.2). ${ }^{1} \mathrm{H}$ NMR (400 MHz, $\mathrm{CDCl}_{3}$ ): $\delta 8.16$ (d, 2H, $J=5.32$ $\mathrm{Hz}), 7.61$ (d, 2H, $J=3.8 \mathrm{~Hz}), 7.34-7.30(\mathrm{~m}, 2 \mathrm{H}) .{ }^{13} \mathrm{C}$ NMR $\left(100 \mathrm{MHz}, \mathrm{CDCl}_{3}\right): \delta$ 142.4, 138.0, 136.3, 134.9, 130.2, 129.4. HRMS (ESI+): calculated for $\mathrm{C}_{12} \mathrm{H}_{6} \mathrm{~S}_{6} \mathrm{Se}_{2}, 501.7124$; found 501.7051 .

2f: Deep orange solid. Yield: $118 \mathrm{mg}, 21 \%$. M.p.: $194{ }^{\circ} \mathrm{C}$. UV-vis in DCM: $\lambda_{\max }(\mathrm{nm})\left(10^{-4} \times \varepsilon\left(\mathrm{M}^{-1} \mathrm{~cm}^{-1}\right)\right)=261$ (4.0), 429 (4.5). ${ }^{1} \mathrm{H}$ NMR (400 MHz, $\mathrm{C}_{6} \mathrm{D}_{6}$ ): $\delta$ 6.96-6.92 (m, 4H), 6.81 $(\mathrm{d}, 2 \mathrm{H}, J=3.8 \mathrm{~Hz}), 6.70(\mathrm{~d}, 2 \mathrm{H}, J=3.84 \mathrm{~Hz}), 6.61(\mathrm{~m}, 2 \mathrm{H}) \cdot{ }^{13} \mathrm{C}$ NMR $\left(100 \mathrm{MHz}, \mathrm{C}_{6} \mathrm{D}_{6}\right): \delta 150.4,148.4,147.2,143.4,139.3$, 139.2, 127.3, 124.8, 124.3, 120.0. HRMS (ESI+): calculated for $\mathrm{C}_{20} \mathrm{H}_{10} \mathrm{~S}_{10}, 569.7990$; found 569.8073 .

\section{Theoretical methods}

Single point TD-DFT calculations were performed on the structure obtained from the single crystal X-ray diffraction of $\mathbf{2 d}$ and $2 \mathrm{e}$ by using the Gaussian 09 programme ${ }^{37}$ at the B3LYP/6$31 \mathrm{G}(\mathrm{d})$ level.

\section{Acknowledgements}

We thank DST, India for funding. SD thanks UGC and AB thanks CSIR for a research fellowship.

\section{References}

1 W. Ni, X. Wan, M. Li, Y. Wang and Y. Chen, Chem. Commun., 2015, 51, 4936.

2 Handbook of Thiophene-Based Materials, ed. I. F. Perepichka and D. F. Perepichka, Wiley-VCH, Chichester, UK, 2009.

3 P. Furuta, J. Brooks, M. E. Thompson and J. M. J. Fréchet, J. Am. Chem. Soc., 2003, 125, 13165.

4 C. Wang, H. Dong, W. Hu, Y. Liu and D. Zhu, Chem. Rev., 2012, 112, 2208.

5 Y. S. Yang, T. Yasuda, H. Kakizoe, H. Mieno, H. Kino, Y. Tateyama and C. Adachi, Chem. Commun., 2013, 49, 6483.

6 P. M. Beaujuge and J. M. J. Fréchet, J. Am. Chem. Soc., 2011, 133, 20009.

7 K. Feng, X. Xu, Z. Li, Y. Li, K. Li, T. Yu and Q. Peng, Chem. Commun., 2015, 51, 6290.

8 Y. Liang, D. Feng, Y. Wu, S. T. Tsai, G. Li, C. Ray and L. Yu, J. Am. Chem. Soc., 2009, 131, 7792.

9 X. He, J. Borau-Garcia, A. Y. Y. Woo, S. Trudel and T. Baumgartner, J. Am. Chem. Soc., 2013, 135, 1137.

10 A. Bedi, S. Debnath and S. S. Zade, Chem. Commun., 2014, 50, 13454.

11 B. L. Chenard, R. L. Harlow, A. L. Johnson and S. A. Vladuchick, J. Am. Chem. Soc., 1985, 107, 3871.

12 L. S. Konstantinova, O. A. Rakitin, C. W. Rees, L. I. Souvorova, D. G. Golovanov and K. A. Lyssenko, Org. Lett., 2003, 5, 1939.

13 S. A. Amelichev, L. S. Konstantinova, O. A. Rakitin and C. W. Rees, Mendeleev Commun., 2006, 16, 289.

14 M. J. Earle, A. G. Massey, A.-R. AL-Soudani and T. Zaidi, Polyhedron, 1989, 8, 2817.

15 B. L. Chenard and T. J. Miller, J. Org. Chem., 1984, 49, 1221. 16 D. Aebisher, E. M. Brzostowska, N. Sawwan, R. Ovalle and A. Greer, J. Nat. Prod., 2007, 70, 1492.

17 E. M. Brzostowska and A. Greer, J. Org. Chem., 2004, 69, 5483.

18 D. J. Schipper, L. C. H. Moh, P. Müller and T. M. Swager, Angew. Chem., Int. Ed., 2014, 53, 5847.

19 I. D. Campbell and G. Eglinton, Org. Synth., 1965, 45, 39.

20 Y. Arakawa, S. Nakajima, R. Ishige, M. Uchimura, S. Kang, G.-i. Konishi and J. Watanabe, J. Mater. Chem., 2012, 22, 8394.

21 G. Zhang, H. Yi, H. Chen, C. Bian, C. Liu and A. Lei, Org. Lett., 2014, 16, 6156.

22 M. D. Curtis, J. Cao and J. W. Kampf, J. Am. Chem. Soc., 2004, 126, 4318.

23 Y. H. Wijsboom, A. Patra, S. S. Zade, Y. Sheynin, M. Li, L. J. W. Shimon and M. Bendikov, Angew. Chem., Int. Ed., 2009, 48, 5443.

24 M. Turbiez, P. Freère, M. Allain, N. Gallego-Planas and J. Roncali, Macromolecules, 2005, 38, 6806.

25 Y. Liu, C. Di, C. Du, Y. Liu, K. Lu, W. Qiu and G. Yu, Chem. - Eur. J., 2010, 16, 2231.

26 X. C. Li, H. Sirringhaus, F. Garnier, A. B. Holmes, S. C. Moratti, N. Feeder, W. Clegg, S. J. Teat and R. H. Friend, J. Am. Chem. Soc., 1998, 120, 2206. 
27 S. Ahn, K. Yabumoto, Y. Jeong and K. Akagi, Polym. Chem., 2014, 5, 6977.

28 T. T. Ong, S. C. Ng and H. S. O. Chan, Polymer, 2003, 44, 5597.

29 B. Dong, Y. Xing, J. Xu, L. Zheng, J. Hou and F. Zhao, Electrochim. Acta, 2008, 53, 5745.

30 M. Heeney, W. Zhang, D. J. Crouch, M. L. Chabinyc, S. Gordeyev, R. Hamilton, S. J. Higgins, I. McCulloch, P. J. Skabara, D. Sparrowea and S. Tierneya, Chem. Commun., 2007, 5061.

31 A. Patra and M. Bendikov, J. Mater. Chem., 2010, 20, 422.

32 W. T. Neo, L. M. Loo, J. Song, X. Wang, C. M. Cho, H. S. O. Chan, Y. Zonga and J. Xu, Polym. Chem., 2013, 4, 4663.

33 S. Kaur, N. J. Findlay, A. L. Kanibolotsky, S. E. T. Elmasly, P. J. Skabara, R. Berridge, C. Wilsonc and S. J. Coles, Polym. Chem., 2012, 3, 2277.

34 O. V. Dolomanov, L. J. Bourhis, R. J. Gildea, J. A. K. Howard and H. Puschmann, OLEX2:a complete structure solution, refinement and analysis program, J. Appl. Crystallogr., 2009, 42, 339-341.

35 L. Palatinus and G. Chapuis, J. Appl. Crystallogr., 2007, 40, 786-790.
36 SHELXL, G. M. Sheldrick, Acta Crystallogr., Sect. A: Found. Crystallogr., 2008, A64, 112-122.

37 M. J. Frisch, G. W. Trucks, H. B. Schlegel, G. E. Scuseria, M. A. Robb, J. R. Cheeseman, G. Scalmani, V. Barone, B. Mennucci, G. A. Petersson, H. Nakatsuji, M. Caricato, X. Li, H. P. Hratchian, A. F. Izmaylov, J. Bloino, G. Zheng, J. L. Sonnenberg, M. Hada, M. Ehara, K. Toyota, R. Fukuda, J. Hasegawa, M. Ishida, T. Nakajima, Y. Honda, O. Kitao, H. Nakai, T. Vreven, J. A. Montgomery Jr., J. E. Peralta, F. Ogliaro, M. Bearpark, J. J. Heyd, E. Brothers, K. N. Kudin, V. N. Staroverov, R. Kobayashi, J. Normand, K. Raghavachari, A. Rendell, J. C. Burant, S. S. Iyengar, J. Tomasi, M. Cossi, N. Rega, J. M. Millam, M. Klene, J. E. Knox, J. B. Cross, V. Bakken, C. Adamo, J. Jaramillo, R. Gomperts, R. E. Stratmann, O. Yazyev, A. J. Austin, R. Cammi, C. Pomelli, J. W. Ochterski, R. L. Martin, K. Morokuma, V. G. Zakrzewski, G. A. Voth, P. Salvador, J. J. Dannenberg, S. Dapprich, A. D. Daniels, O. Farkas, J. B. Foresman, J. V. Ortiz, J. Cioslowski and D. J. Fox, Gaussian 09, Revision E.01, Gaussian Inc., Wallingford CT, 2009. 